\title{
Photosynthetic properties of three Brazilian seaweeds
}

\author{
RICARDO M. CHALOUB ${ }^{1,7}$, FERNANDA REINERT ${ }^{2}$, CRISTINA A. G. NASSAR ${ }^{3}$, \\ BEATRIZ G. FLEURY ${ }^{4}$, DULCE G. MANTUANO ${ }^{5}$ and ANTHONY W. D. LARKUM ${ }^{6}$
}

(received: June 03, 2009; accepted: March 11, 2010)

\begin{abstract}
Photosynthetic properties of three Brazilian seaweeds). Photosynthetic performance of distinct marine macroalgae, Ulva fasciata Delile (green alga), Lobophora variegata (J. V. Lamouroux) Womersley ex E. C. Oliveira (brown alga), and Plocamium brasiliensis (Greville) M. A. Howe \& W. R. Taylor (red alga), were compared using a pulse amplitude-modulated fluorometer. The maximum quantum yield $\left(F_{v} F_{m}\right)$ ranged from 0.80 to 0.51 , and the lowest value was found in P. brasiliensis. Under $400 \mu \mathrm{mol}$ photons $\mathrm{m}^{-2} \mathrm{~s}^{-1}$ irradiance, the highest value of photochemical quenching ( $\left.\mathrm{qP}=0.92 \pm 0.13\right)$ was observed for $U$. fasciata. The red alga $P$. brasiliensis dissipated high amounts of excitation energy (qN $=0.56 \pm 0.09$ ), resulting in relatively low values for the effective quantum yield of PS-II $(0.23 \pm 0.04)$, as well as for the relative electron transport rate $(3.3 \pm 0.7)$. The high photosynthetic potential found for $U$. fasciata partially explains the species ability for rapid growth and high productivity.
\end{abstract}

Key words - Chlorophyll fluorescence, Lobophora variegata, Plocamium brasiliensis, Ulva fasciata

RESUMO - (Propriedades fotossintéticas de três macroalgas marinhas brasileiras). O desempenho fotossintético de três grupos distintos de macroalgas marinhas, Ulva fasciata Delile (alga verde), Lobophora variegata (J. V. Lamouroux) Womersley ex E. C. Oliveira (alga parda) e Plocamium brasiliensis (Greville) M. A. Howe \& W. R. Taylor (alga vermelha), foi comparado com auxílio de um fluorímetro de pulso e amplitude modulada. O potencial fotoquímico máximo do PS II $\left(F_{v} / F_{m}\right)$ variou de 0,80 a 0,51 , sendo que os menores valores foram observados em $P$. brasiliensis. Sob a irradiância de $400 \mu \mathrm{mol}$ fótons $\mathrm{m}^{-2} \mathrm{~s}^{-1}$, o maior valor de dissipação fotoquímica $(\mathrm{qP}=0,92 \pm 0,13)$ foi observado para $U$. fasciata. A alga vermelha $P$. brasiliensis dissipou elevada quantidade de energia de excitação ( $\mathrm{qN}=0,56 \pm 0,09)$, resultando em valores baixos de potencial fotoquímico efetivo do PS II $(0,23 \pm 0,04)$, e também de taxa relativa de transporte de elétrons $(3,3 \pm 0,7)$. O elevado potencial fotossintético encontrado para U. fasciata explica, parcialmente, a capacidade da espécie de crescimento rápido e de alta produtividade.

Palavras-chave - fluorescência da clorofila, Lobophora variegata, Plocamium brasiliensis, Ulva fasciata

\section{Introduction}

Chlorophyll fluorescence analysis allows noninvasive and fast measurements of key aspects of photosynthetic light capture and electron transport.

1. Universidade Federal do Rio de Janeiro, Departamento de Bioquímica. Av. Athos da Silveira Ramos, 149, Bloco A do Centro de Tecnologia, Ilha do Fundão, 21941-909 Rio de Janeiro, RJ, Brazil.

2. Universidade Federal do Rio de Janeiro, Departamento de Biologia Vegetal. Av. Carlos Chagas Filho, 373, Bloco A do Centro de Ciências da Saúde, Ilha do Fundão, 21941-902 Rio de Janeiro, RJ, Brazil.

3. Universidade Federal do Rio de Janeiro, Departamento de Biologia Marinha. Av. Carlos Chagas Filho, 373, Bloco A do Centro de Ciências da Saúde, Ilha do Fundão, 21941-902 Rio de Janeiro, RJ, Brazil.

4. Universidade do Estado do Rio de Janeiro, Departamento de Ecologia. Rua São Francisco Xavier, 524 - PHLC, Maracanã, 20559-900 Rio de Janeiro, RJ, Brazil.

5. Instituto de Pesquisas Jardim Botânico do Rio de Janeiro, Departamento de Botânica Estrutural. Rua Jardim Botânico, 1008, Jardim Botânico, 22460-070 Rio de Janeiro, RJ, Brazil.

6. University of Sydney, School of Biological Sciences (A08), New South Wales 2006, Sydney, Australia.

7. Corresponding author: chaloub@iq.ufrj.br
For biological systems at room temperature, the overall chlorophyll fluorescence yield is usually low and most of the fluorescence emission originates from PSII antenna pigments (Krause \& Weis 1991). Although PSII fluorescence is a minor pathway for excitation dissipation, it competes with the quantitatively more important energy dissipation routes of PSII photochemistry, such as excitation transfer to PSI and heat dissipation. Therefore, changes in photochemistry or in the two nonphotochemical routes (energy and heat emission) cause changes in the fluorescence yield from PSII (Krause \& Weis 1991; Bolhàr-Nordenkampf \& Öquist 1993).

Pulse amplitude-modulated (PAM) fluorescence measuring systems, originally developed for higher plants, have been used to measure chlorophyll fluorescence from algae and cyanobacteria (Schreiber et al. 1986, Büchel \& Wilhelm 1993, Schreiber et al. 1995, Mouget \& Tremblin 2002, Molina-Montenegro et al. 2005), as well as from photosymbiont-containing invertebrates such as corals (Yellowlees et al. 2003) and sponges (Beer 
\& Ilan 1998). In this study, a pulse amplitude-modulated fluorometer was used to assess photosynthetic properties of three tropical seaweeds (green, brown and red algae). Lobophora variegata (J.V. Lamouroux) Womersley ex E. C. Oliveira (Heterokontophyta) and Ulva fasciata Delile (Chlorophyta) are widely distributed along the Brazilian coast from shallow waters up to depths of 26 and $13 \mathrm{~m}$, respectively (Horta 2000). In contrast, Plocamium brasiliensis (Greville) M. A. Howe \& W. R. Taylor (Rhodophyta) is restricted to the southern and southeastern coast of Brazil, growing from the intertidal zone to depths of $22 \mathrm{~m}$ (Horta 2000). The thalli of the first two species are foliose and expanded while $P$. brasiliensis thallus is foliose and abundantly branched. Comparative studies on the photosynthetic responses of different groups of tropical seaweeds are scarce (Necchi Júnior 2004), and this study was initiated as a contribution to reduce this gap.

\section{Material and methods}

Algal material - Specimens of the green alga Ulva fasciata, the brown alga Lobophora variegata and the red alga Plocamium brasiliensis were collected from Praia do Forno

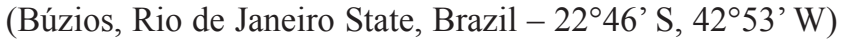
in March 2006. U. fasciata occurred in the intertidal and upper sub-littoral zone of rocky shores, while $L$. variegata and $P$. brasiliensis were found in the upper sub-littoral zone of the beach. Samples were collected from the rocky shore at $1 \mathrm{~m}$ depth and immediately placed in a vessel with seawater at $22{ }^{\circ} \mathrm{C}$ (ambient seawater temperature). The vessel was maintained in darkness for at least 20 minutes prior to fluorescence measurements. Three thalli of each species were used for measurements.

Chlorophyll- $a$ fluorescence measurements - Chlorophyll fluorescence parameters were measured using a submersible diving-PAM system (Walz, Effeltrich, Germany), equipped with a blue LED $(470 \mathrm{~nm})$. The minimal fluorescence level in the dark-adapted state $\left(F_{o}\right)$ was elicited by a weak probe of modulated light, whereas the maximum fluorescence level $\left(F_{m}\right)$ was detected after a saturating pulse of actinic light $\left(10,000 \mu \mathrm{mol}\right.$ photons $\left.\mathrm{m}^{-2} \mathrm{~s}^{-1}\right)$, which is sufficient to close all reaction centers and drive photochemical quenching to zero. Variable fluorescence of dark-adapted samples $\left(F_{v}\right)$ was calculated from $F_{m}-F_{o}$, and the maximum quantum efficiency of PS-II photochemistry was obtained from the ratio $F_{v} / F_{m}$. Samples were also exposed to $400 \mu \mathrm{mol}$ photons $\mathrm{m}^{-2} \mathrm{~s}^{-1}$ until steady-state fluorescence emission $\left(F_{s}\right)$ was obtained, and maximum fluorescence signal $\left(F_{m}{ }^{\prime}\right)$ of light-adapted samples was determined after a saturating pulse of actinic light. The effective quantum efficiency of PS-II $\left(\Phi_{\mathrm{PS}-\mathrm{II}}=F_{m}{ }^{\prime}-F_{s} / F_{m}{ }^{\prime}\right)$ was obtained from light-adapted samples. The proportion of open PSII reaction centers under actinic light was determined by the photochemical quenching coefficient, $\mathrm{qP}=\left(F_{m}{ }^{2}-F_{s}\right) /$ $\left(F_{m}{ }^{\prime}-F_{o}\right)$, and the nonphotochemical quenching coefficient calculated from qN $=\left(F_{m}-F_{m}{ }^{\prime}\right) /\left(F_{m}-F_{o}\right)$. The relative electron transport rate (rETR) was computed by using the equation $\mathrm{ETR}=$ PAR $0.5 \Phi_{\text {PS-II }} 0.84$ (Genty et al. 1989).

Statistics - Mean values were compared using Kruskal Wallis non-parametric ANOVA at 5\% significance level $(P<0,05)$, using the software GraphPadInStat 3.01 (GraphPad Software Inc.).

\section{Results and discussion}

The three seaweed species showed significantly different responses in fluorescence parameters, although they occurred at similar positions on the boulders, and were, therefore, exposed to similar irradiances. Maximum quantum efficiency $\left(F_{\sqrt{ }} / F_{m}\right.$ of dark-adapted samples) was significantly lower in $P$. brasiliensis and higher in $U$. fasciata than in L. variegata (figure 1A), suggesting that the red alga was photoinhibited at the highest light levels around noontime. In addition, the highest values observed in U. fasciata (0.80-0.83), seem to indicate an increased PSII function in comparison with the other two species.

The values for $\mathrm{qP}$ were not significantly different among the three species (figure 1B). Given that $\mathrm{qP}$ reflects the proportion of the PSII reaction centers in the open state, high values of $\mathrm{qP}$ can result either from high rates of electron transfer around PSII (high rates of $\mathrm{Q}_{\mathrm{A}}$ re-oxidation) or from the occurrence of high nonphotochemical quenching processes. As qN describes any nonphotochemical process that reduces the yield of variable fluorescence, the lowest values for this parameter in U. fasciata (figure 1B) confirm that this alga efficiently utilizes trapped light energy. This is in agreement with high values of both photochemical yield of electron transport around PSII ( $\Phi_{\text {PS-II }}$, figure $\left.1 \mathrm{C}\right)$ and relative electron transport rate (rETR, figure 1D) observed for this species. In contrast, it is evident in figure $1 \mathrm{~B}$ that a higher amount of excitation energy is dissipated by nonphotochemical processes in $P$. brasiliensis than in the other two species, resulting in low values of $\Phi_{\text {PS-II }}$ and rETR (figure $1 \mathrm{C}$ and 1D). These results suggest that $P$. brasiliensis is a shade adapted species in accordance with the results found for another red alga Palmaria palmata (Linnaeus) Kuntze from the French coastline (Mouget \& Trembling 2002). Under light intensities ranging from 10 to $150 \mu \mathrm{mol} \mathrm{m} \mathrm{m}^{-2} \mathrm{~s}^{-1}$, P. palmata exhibited the lowest $\Phi_{\mathrm{PS}-\mathrm{II}}$ and $\mathrm{qP}$ values, as well as the highest level of energy dissipation through nonphotochemical quenching, in comparison to Ulva sp. and the brown alga 
Fucus serratus Linnaeus (Mouget \& Trembling 2002). Previous studies with freshwater algae also showed that the rhodophytes were typically shade-adapted plants and some of them can tolerate high irradiances due to the presence of high nonphotochemical quenching (Necchi Júnior 2005). Since the fluorescence parameters found in
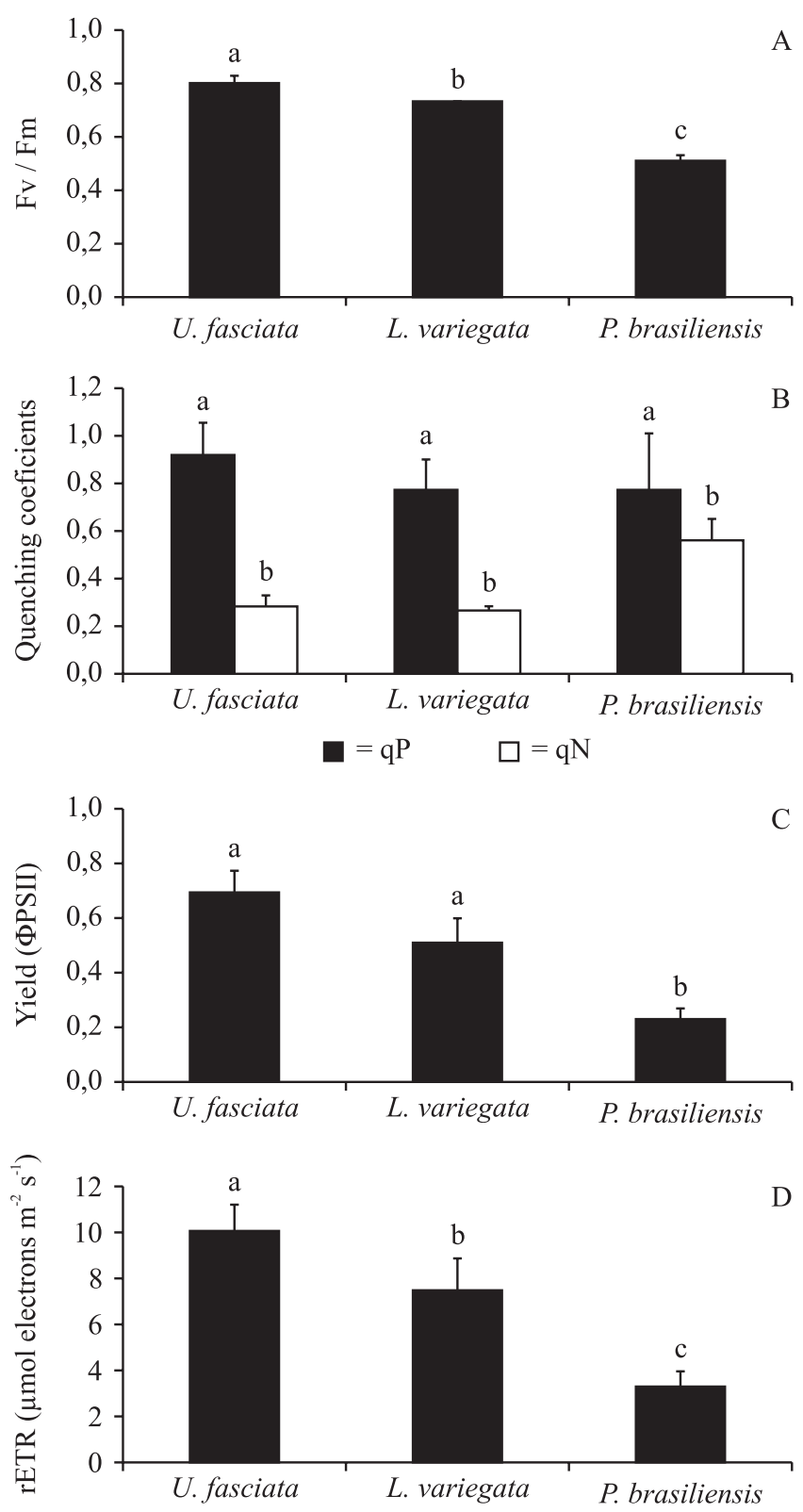

Figure 1. Photosynthetic parameters of three seaweeds: Ulva fasciata, Lobophora variegata and Plocamium brasiliensis. A. $F_{v} / F_{m}$, the maximum PS-II quantum efficiency of darkadapted samples. B. $\mathrm{qP}$ and $\mathrm{qN}$, the photochemical and nonphotochemical quenching coefficients, respectively. C. $\Phi_{\text {PS-II }}$, the effective PS-II quantum efficiency of illuminated samples. D. rETR, the relative electron transport rate. Distinct low caption letters represent statistically different means at $P<0.05$, and bars represent standard deviations.
L. variegata were close to those found in the green alga, an efficient photosynthetic apparatus is also assumed to occur in this Dictyotales. Similar results were previously observed in L. variegata sampled from deep-water near Bermuda (Peckol \& Ramus 1992).

Our results support the view of rapid growth potential and high net primary productivity of the opportunistic macroalgae $U$. fasciata as previously reported (Littler \& Littler 1980, Mouget \& Tremblin 2002). The sampling site can be subjected to drastic changes in water temperature during the summer, due to the upwelling phenomenon that occurs in the proximity (Valentin et al. 1978). High solar irradiation allied to cold water can change photosynthetic rates and increase photoinhibition (Gomez et al. 2001). Such conditions represent a natural laboratory for studies in the tropics and a better understanding of the photosynthetic responses of the macroalgal community is of major importance in the present scenario of potential global weather changes.

Acknowledgement - We are indebted to Dr. Marcia Creed for organizing a workshop on chlorophyll fluorescence with the presence of Dr. Anthony W. D. Larkum funded by CNPq.

\section{References}

BEER, S. \& ILAN, M. 1998. In situ measurements of photosynthetic irradiance responses of two Red Sea sponges growing under dim light conditions. Marine Biology 131:613-617.

BOLHÀR-NORDENKAMPF, H.R. \& ÖQUIST, G. 1993. Chlorophyll fluorescence as a tool in photosynthesis research. In Photosynthesis and production in a changing environment: a field and laboratory manual (D. Hall, J.M.O. Scurlock, H.R.R. Bolhàr-Nordenkampf, C.R.C. Leegood, S.P. Long, eds.). Chapman \& Hall, London, p.193-206.

BÜCHEL, C. \& WILHELM, C. 1993. In vivo analysis of slow chlorophyll fluorescence induction kinetics in algae: progress, problems, and perspectives. Photochemistry and Photobiology 58:137-148.

GENTY, B., BRIANTAIS, J.-M. \& BAKER, N.R. 1989. The relationship between the quantum yield of photosynthetic electron transport and quenching of chlorophyll fluorescence. Biochimica et Biophysica Acta 990:87-92.

GOMEZ, I., FIGUEROA, F.L., SOUSA-PINTO, I., VINEGLA, B., PEREZ-RODRIGUEZ, E., MAESTRE, C., COElHo, S., FElGA, A. \& PEREIRA, R. 2001. Effects of UV radiation and temperature on photosynthesis as measured by PAM fluorescence in the red alga Gelidium pulchellum (Turner) Kutzing. Botanica Marina 44:9-16. 
HORTA, P.A. 2000. Macroalgas do infralitoral do sul e sudeste brasileiro. Tese de doutorado. Universidade de São Paulo, São Paulo.

KRAUSE, G.H. \& WEIS, E. 1991. Chlorophyll fluorescence and photosynthesis: the basics. Review of Plant Physiology and Plant Molecular Biology 42:313349.

LITLLER, M.M. \& LITTLER, D.S. 1980. The evolution of thallus form and survival strategies in benthic marine macroalgae: field and laboratory tests of a functional form model. The American Naturalist 116: 25-44.

MOLINA-MONTENEGRO, M.A., MUNOZ, A.A., BADANO, E.I., MORALES, B.W., FUENTES, K.M. \& CAVIERES, L.A. 2005. Positive associations between macroalgal species in a rocky intertidal zone and their effects on the physiological performance of Ulva lactuca. Marine Ecology Progress Series 292: 173-180.

MOUGET, J.-L. \& TREMBLIN, G. 2002. Suitability of the fluorescence monitoring system (FMS, Hansatech) for measurement of photosynthetic characteristics in algae. Aquatic Botany 74:219-231.

NECCHI JUNIOR, O. 2004. Photosynthetic responses to temperature in tropical lotic macroalgae. Phycological Research 52:140-148.
NECCHI JUNIOR, O. 2005. Light-related photosynthetic characteristics of freshwater rhodophytes. Aquatic Botany 82:193-209.

PECKOL, P. \& RAMUS, J. 1992. Photosynthetic performance of deep-water macroalgae (Phaeophyta, Dictyotales) of Bermuda. Hydrobiologia 231:93-98.

SCHREIBER, U., SCHLIWA, U. \& BILGER, W. 1986. Continuous recording of photochemical and nonphotochemical chlorophyll fluorescence quenching with a new type of modulation fluorometer. Photosynthesis Research 10:51-62.

SCHREIBER, U., ENDO, T., MI, H. \& ASADA, K. 1995. Quenching analysis of chlorophyll fluorescence by the saturation pulse method: particular aspects relating to the study of eukaryotic algae and cyanobacteria. Plant \& Cell Physiology 36:873-882.

VALENTIN, J.L., ANDRE, D.L., MONTEIRO-RIBAS, W.N.M. \& TENENBAUM, D.R. 1978. Hidrologia e plâncton da região costeira entre Cabo Frio e o estuário do Rio Paraíba (Brasil). Instituto de Pesquisas da Marinha 127:1-24.

YELLOWLEES, D. \& WARNER, M. 2003. Photosynthesis in symbiotic algae. In Photosynthesis in Algae (A.W.D. Larkum, S.E. Douglas \& J.A. Raven, eds.). Advances in photosynthesis and respiration 14. Springer, Dordrecht, p.437-455. 